\title{
Antibacterial Activities of Asmina triloba against Some Bacterial Pathogens
}

\author{
Abalaka M. E, Oyewole O. A.* \\ Department of Microbiology, Federal University of Technology, PMB 65, Minna, Niger State, Nigeria
}

\begin{abstract}
The antibacterial effect of Asmina triloba against Pseudomonas aeruginosa, Klebsiella ozanae, Staphylococcus aureus and Escherichia coli was determined using the agar cup plate technique. The phytochemical components of Asmina triloba showed the presence of alkaloids and phlobatanin and the absence of saponin, tannins, phenolics, glycosides, flavonoids and triterpenes. The results showed that the test organisms were susceptible to $500 \mathrm{mg} / \mathrm{ml}, 50 \mathrm{mg} / \mathrm{ml}$ and $5 \mathrm{mg} / \mathrm{ml}$ of the plant extract. The minimum inhibitory concentration (MIC) and minimum bactericidal concentration (MBC) were determined. The result showed that the MIC for Pseudomonas aeruginosa and Klebsiella ozanae was $500 \mathrm{mg} / 1$ and the MIC of $50 \mathrm{mg} / 1$ was recorded for $S$. aureus and E.coli. No MBC was recorded for both P. aeruginosa and K. ozanae but MBC for $S$. aureus and $E$. coli was $500 \mathrm{mg} / 1$. The results of the study suggest that extracts of Asmina triloba could be suitable for the treatment of various infections caused by $P$. aeruginosa, K. ozanae, S. aureus and E. coli.
\end{abstract}

Keywords Antibacterial Effect, Asmina triloba, Phytochemical Components, Minimum Inhibitory Concentration, Minimum Bactericidal Concentration

\section{Introduction}

The term herbal drug determines the part/parts of a plant used for preparing herbal and traditional medicines (for examples: leaves, flowers, seeds, roots, barks, stems, etc.) (Kayode and Kayode, 2011) Furthermore, World Health Organization, WHO (2001) defines medicinal plant as herbal preparations produced by subjecting plant materials to extraction, fractionation, purification, concentration or other physical or biological processes which may be produced for immediate consumption or as a basis for herbal products. Medicinal plants contain biologically active chemical substances such as saponins, tannins, essential oils, flavonoids, alkaloids and other chemical compounds (Sofowora, 1996) which have curative properties. These complex chemical substances of different compositions are found as secondary plant metabolites in one or more of these plants. Tyler (1999) has reported that plants also contain certain other compounds that moderate the effects of the active ingredients.

North American pawpaw (Asmina trilobota) is the largest tree fruit native to temperate North America. It is an underutilized plant that has potential as landscape tree, fruit crop and as a source of pharmaceutical products (Finneseth et al., 2000). In addition, A. triloba has some identified secondary products (acetoginins) in the bark and leaves that have a wide

* Corresponding author:

gapsmeb2003@yahoo.co.uk (Oyewole, O. A.)

Published online at http://journal.sapub.org/microbiology

Copyright (C) 2011 Scientific \& Academic Publishing. All Rights Reserved range of biological activities including anticancer, antimicrobial, immune suppressant and pesticidal properties (Finneseth et al., 2000).

This study was undertaken therefore, to determine the phytochemical components of the leaf extracts of A. triloba, the minimum inhibitory concentration (MIC) of the extract on Pseudomonas aeruginosa, Klebsiella ozanae, Staphylococcus aureus and Escherichia coli, the minimum bactericidal concentration (MBC) of the extract on Pseudomonas aeruginosa, Klebsiella ozanae, Staphylococcus aureus and Escherichia coli.

\section{Materials and Methods}

\section{Collection and Preparation of Samples}

The bark of A. triloba was collected from different locations in Minna metropolis. It was air-dried for six weeks in microbiology laboratory of Federal University of Technology, Minna. The dried materials were pulverised in mortar and packaged in bottles for analysis.

\section{Collection of Specimen}

Pure cultures of Pseudomonas aeruginosa, Klebsiella ozanae, Staphylococcus aureus and Escherichia coli were obtained from General Hospital Minna. Niger State and were subcultured in agar slants.

\section{Extraction of Materials}

Ethanol and water were used as solvents for the extraction of the plant materials. $150 \mathrm{~g}$ of pulverised sample was sus- 
pended in $750 \mathrm{ml}$ of $75 \%$ ethanol for 120 hours. The extracts were decanted, filtered and evaporated in vacuole at 450C.

\section{Phytochemical Screening of Extracts of Asmina triloba}

The phytochemical components of extracts of A. triloba was determined using methods described by Odebiyi and Sofowora (1978) and Trease and Evans (1989). The phytochemical components analysed for were alkaloids, tannins, phenolics, glycosides. saponins, flavonoids, steroids, phlobatanins and triterpenes.

\section{Antimicrobial Susceptibility Test}

Susceptibility test of the test organisms to extracts of $A$. triloba at concentrations of $500 \mathrm{mg} / \mathrm{ml}, 50 \mathrm{mg} / \mathrm{ml}$ and $5 \mathrm{mg} / \mathrm{ml}$ was carried out using agar cup plate technique as described by Silver et al. (1997). Nutrient agar was prepared using autoclave at $121^{\circ} \mathrm{C}$ for 15 minutes. It was then poured on to plates and allowed to solidify. Standardized inoculum of each test organisms was spread on to agar plates so as to achieve a confluent growth. The impregnated discs with different concentration of the extract were placed on the surface of the medium at three points equidistant from one another. The plates were then incubated at $37^{\circ} \mathrm{C}$ for 24 hours.

\section{Determination of Minimum Inhibitory Concentration (MIC)}

The minimum inhibitory concentration (MIC) of the test organisms was determined using the tube dilution technique. $9 \mathrm{ml}$ of the nutrient broth was pippeted into various test tubes containing concentrations of $500 \mathrm{mg} / \mathrm{ml}, 50 \mathrm{mg} / \mathrm{ml}$ and 5 $\mathrm{mg} / \mathrm{ml}$ of the extract. The overnight culture of the test organisms diluted at $10^{6} \mathrm{cfu} / \mathrm{ml}$ was added to the test tubes and then incubated at $37^{\circ} \mathrm{C}$ for 24 hours. The least concentration of the extract that did not indicate any visible growth of the incubated organisms in broth culture was taken as the minimum inhibitory concentration (MIC) (Hugo and Russel, 1983).

\section{Results}

\section{Phytochemical Screening of the Extracts}

Table 1 shows the phytochemical screening of the extract of $A$. triloba. The phytochemical components of A. triloba showed the presence of alkaloid and phlobatanin but the absence of tannins, phenolics, glycosides, saponin, flavonoids and triterpenes.

\section{Antimicrobial Activities of the Extracts}

Table 2 shows the zones of inhibition ( $\mathrm{mm}$ ) of extract of $A$. triloba at different concentrations $(\mathrm{mg} / \mathrm{ml})$. At $500 \mathrm{mg} / \mathrm{ml}, P$. aeruginosa and E. coli had a zone of inhibition of $11 \pm$ $2.08 \mathrm{~mm}$ and $S$. aureus had the least zone of inhibition of $5 \pm$ $1 \mathrm{~mm}$. At $50 \mathrm{mg} / \mathrm{ml}, P$. aeruginosa had the highest zone of inhibition of $12 \pm 8 \mathrm{~mm}$ and the least zone of inhibition of $6 \pm$ $1 \mathrm{~mm}$ was obtained by $S$. aureus. At $5 \mathrm{mg} / \mathrm{ml}$, S. aureus was not sensitive to extract of $A$. triloba but $P$. aeruginosa had the highest zone of inhibition of $9 \pm 1.5 \mathrm{~mm}$.

Table 1. Phytochemical screening of the extracts of A. triloba

\begin{tabular}{ccc}
\hline S/no & Component & A. triloba \\
\hline $\mathbf{1}$ & Alkaloid & + \\
$\mathbf{2}$ & Tannins & - \\
$\mathbf{3}$ & Phenolics & - \\
$\mathbf{4}$ & Glycoside & - \\
$\mathbf{5}$ & Saponin & - \\
$\mathbf{6}$ & Flavonoid & - \\
$\mathbf{7}$ & Phlobtanin & + \\
$\mathbf{8}$ & Triterpenes & - \\
\hline
\end{tabular}

Key: $+=$ Present $-=$ Absent

Table 2. Antimicrobial activities of the extracts

\begin{tabular}{cccc}
\hline Organisms & \multicolumn{3}{c}{ Concentration of extract of $\boldsymbol{A}$. triloba } \\
\hline & $500 \mathrm{mg} / 1$ & $50 \mathrm{mg} / 1$ & $5 \mathrm{mg} / 1$ \\
P. aeruginosa & $11 \pm 2.08 \mathrm{~mm}$ & $12 \pm 8 \mathrm{~mm}$ & $9 \pm 1.5 \mathrm{~mm}$ \\
K. ozanae & $7.7 \pm 0.6 \mathrm{~mm}$ & $8 \pm 2 \mathrm{~mm}$ & $5 \pm 1 \mathrm{~mm}$ \\
S. aureus & $5 \pm 1 \mathrm{~mm}$ & $6 \pm 1 \mathrm{~mm}$ & - \\
E. coli & $11 \pm 2.08 \mathrm{~mm}$ & $11 \pm 2.08 \mathrm{~mm}$ & $6 \pm 1 \mathrm{~mm}$ \\
\hline
\end{tabular}

Minimum inhibitory concentration (MIC) and minimum bactericidal concentration (MBC) of Extract of A. triloba on the test organisms

Table 3 shows the minimum inhibitory concentration and minimum bactericidal concentration of the test organism on the extract of $A$. triloba. The minimum inhibitory concentration for Pseudomonas aeruginosa, K. ozanae, S. aureus and E. coli was $500 \mathrm{mg} / 1$. Pseudomonas aeruginosa and $K$. ozanae had no MBC but $S$. aureus and E. coli had MBC values of $500 \mathrm{mg} / \mathrm{ml}$.

Table 3. Minimum inhibitory concentration (MIC) and minimum bactericidal concentration (MBC)

\begin{tabular}{ccc}
\hline Organisms & MIC $(\mathbf{m g} / \mathbf{l})$ & MBC $(\mathbf{m g} / \mathbf{l})$ \\
\hline P. aeruginosa & 500 & - \\
K.ozanae & 500 & - \\
S. aureus & 500 & 500 \\
E. coli & 500 & 500 \\
\hline
\end{tabular}

Susceptibility Testing using Standard Antibiotics (Positive control)

Table 4 shows the susceptibility result of standard antibiotics against the test organisms. $P$. aeruginosa was only sensitive to Amoxacillin (AMX). K. ozanae was sensitive to all antibiotics tested except Augmentin (AU) and Ceporex (CEP), E. coli was also sensitive to all the antibiotics except Amoxacillin (AMX) and Ceporex (CEP) while S. aureus was not sensitive to Ciprofloxacin (CPX), Ceporex (CEP) and Ampicillin (PN).

Table 4. Susceptibility testing using standard antibiotics

\begin{tabular}{cccccccccc}
\hline organisms & $\mathbf{A M X}(\mathbf{m m})$ & $\mathbf{C P X}(\mathbf{m m})$ & $\mathbf{R D}(\mathbf{m m})$ & $\mathbf{A U}(\mathbf{m m})$ & $\mathbf{C E P}(\mathbf{m m})$ & $\mathbf{G E N}(\mathbf{m m})$ & $\mathbf{P N}(\mathbf{m m})$ & $\mathbf{A U}(\mathbf{m m})$ & $\mathbf{G}(\mathbf{m m})$ \\
\hline P.aeruginosa & $11 \pm 2$ & - & - & - & - & - & - & - & - \\
K.ozanae & $10 \pm 2$ & $19 \pm 2$ & $19 \pm 2$ & - & - & $4 \pm 2.52$ & $11 \pm 4.5$ & $5 \pm 3.05$ & $6 \pm 1.00$ \\
S. aureus & $10 \pm 2$ & - & $10 \pm 2$ & $8 \pm 2$ & - & $7 \pm 2.52$ & - & $7 \pm 2.52$ & $6 \pm 1.00$ \\
E. coli & - & $8 \pm 2$ & $8 \pm 2$ & $12 \pm 8$ & - & $10 \pm 2$ & $6 \pm 1.00$ & $7 \pm 3.00$ & $6 \pm 2.0$ \\
\hline
\end{tabular}

Key: AMX- Amoxacillin, CPX- Ciptrofloxacin, RF- Rifampin, AU- Augmentin, GEN- Gentamycin, CEP-Ceporex, PN- Ampicillin, CH- Chloramphenicol, S- Streptomycin 
Susceptibility Testing using Standard Antibiotics (Negative control)

Table 5 shows the susceptibility of the tested organisms on some standard antibiotics. $P$. aeruginosa,K. ozanae, $S$. aureus and Escherichia coli were sensitive to Gentamycin (GEN), Ciprofloxacin (CPX) and Streptomycin (S). Only $S$. aureus and E. coli were sensitive to Ampicillin (PN) and only E. coli was resistant to Augmentin (AU).

Table 5. Susceptibility testing using standard antibiotic

\begin{tabular}{cccccc}
\hline Organisms & $\begin{array}{c}\text { GEN } \\
(\mathbf{m m})\end{array}$ & $\begin{array}{c}\mathbf{C P X} \\
\mathbf{( m m})\end{array}$ & $\begin{array}{c}\mathbf{P N} \\
\mathbf{( m m})\end{array}$ & $\begin{array}{c}\text { AU } \\
\mathbf{( m m})\end{array}$ & $\mathbf{G}(\mathbf{m m})$ \\
\hline P.aeruginosa & $14 \pm 2.08$ & $11 \pm 4.5$ & - & $10 \pm 2.00$ & $5 \pm 3.05$ \\
K.ozanae & $14 \pm 3.06$ & $7 \pm 2.52$ & - & $8 \pm 2.00$ & $6 \pm 1.00$ \\
S. aureus & $11 \pm 1.00$ & $3 \pm 2.82$ & $9 \pm 3.05$ & $10 \pm 2.00$ & $10 \pm 1.53$ \\
E. coli & $8 \pm 2.00$ & $4 \pm 1.53$ & $10 \pm 4.00$ & - & $10 \pm 2.00$ \\
\hline
\end{tabular}

KEY: CPX- Ciprofloxacin, AU- Augmentin, GEN- Gentamycin,

CEP-Ceporex, PN- Ampicillin, S- Streptomycin

\section{Discussion}

The phytochemical components of A. triloba (Table 1) showed the presence of alkaloid and phlobatanin. The presence of these components may be responsible for the antibacterial effects of the bark extract of $A$. triloba. Avalos et al. (1993) reported that alkaloid have a drastic lethal effect on the central nervous system while phlobatanin have protective ability against bacterial and fungal infections. Sofowora (1996) reported that phytochemical components usually interfere with growth and metabolisms of microorganisms. Oderinde et al. (2002) reported that $A$. triloba is use tropically in the treatment of cuts, rashes, stings and burns.

A. triloba shows minimum inhibitory concentration (MIC) value of $500 \mathrm{mg} / \mathrm{ml}$ for $P$. aeruginosa, $K$. ozanae, $S$. aureus and E. coli. MBC values for $P$. aeruginosa and $K$. ozanae was $500 \mathrm{mg} / \mathrm{ml}$ whereas Staphylococcus aureus and E. coli had no MBC value (Table 3). This suggests that the bark extracts of $A$. triloba is bacteriostatic on the tested organisms. According to Prescott et al. (2005), a bacteriostatic agent kills at a much higher concentration whereas drug kills pathogen at levels only two or four times the MIC.

At $500 \mathrm{mg} / \mathrm{ml}$ and $50 \mathrm{mg} / \mathrm{ml}$ and $5 \mathrm{mg} / \mathrm{ml}$, the extracts of $A$. triloba showed a higher susceptibility on $P$. aeruginosa and E. coli. The least zone of inhibition was recorded in $S$. aureus while at $5 \mathrm{mg} / \mathrm{ml}, S$. aureus was resistant (Table 2). When compared with standard antibiotics (Table 4), extracts of $A$. triloba had a higher zone of inhibition on $E$. coli. This may indicate that extracts of $A$. triloba has a higher antibacterial effects on gram negative $E$. coli than the tested antibiotics.

The result of this study shows that at high concentration, bark extract of $A$. triloba has antibacterial effects against $P$. aeruginosa, K.ozanae, S. aureus and E. coli.

\section{REFERENCES}

[1] Avalos, J., Rupprech, J.K., Mclaughlin, J.I., Rodregue, F. (1993). Guines pig maximazatio test of the bark extract from pawpaw, Annoceae 29 (1):33-35

[2] Finneseth, C.L.H, Geneve, R.L. and Layne, D.R. C. (2000). Establishment of North American pawpaw (Asimina triloba (L.) Dunal shoots in vitro from mature explants Pp. 1-6

[3] Hugo, S.B. and Rusell, A.D. (1983). Pharmaceutical Microbiology 3rd Edition. Blackwell Scientific Publication, London pp. 105-125

[4] Kayode A.A.A. and Kayode, O.T. (2011). Some Medicinal Values of Telfairia occidentalis: A Review. American Journal of Biochemistry and Molecular Biology, 1: 30-38

[5] Odebiyi, A. and Sofowora, A.E. (1978). Phytochemical screening of Nigeria medicinal plant part III Lioydia 4: 234-246

[6] Oderinde, O., Noronha, C., Oremosu, A., Kusemiju, T. and Okanlawon, A. (2002). Abortifacient properties of aqueos extract of Carica papaya (Linn) seed on female Sprague-Dawley rat. Nig. Postgrad. Med. J., 9: 95-98

[7] Prescott, L. M., J. P. Harley and D. A. Klein. 2005. Microbiology. Sixth Edition. New York: McGraw-Hill

[8] Silver, O.A., Cabrita, T., Pimentel, M., Diniz, A. and Gomes, E. (1997). Antimicrobial activity of Guinea Bissau traditional remedies. Journal of Ethnopharmacology, 50: 55-59

[9] Sofowora, A., 1996. Medicinal Plant and Traditional Medicine in Africa. 2nd Edn., Spectrum Books, Ibadan, Nigeria, pp: 112

[10] Trease, G.E. and Evans, W.C. (1989). A textbook of pharmagnosy 13th edition. Baluiere, Tindali, London pp. 100-101

[11] Tyler, V.E., 1999. Phytomedicines: Back to the future. J. Nat. Prod., 62: 1589-1592

[12] World Health Organzation (WHO), 2001. Geneva Legal Status of Traditional Medicine and Complementary /Alternative Medicine: A Worldwide Review. World Health Organisation, Geneva, pp: 129-143 